\title{
HAKIKAT ANAK DALAM PERSPEKTIF PENDIDIKAN ISLAM
}

\section{ANGGA YOGASWARA}

\begin{abstract}
Children are an investment in the future, because they are born carrying a pile of hopes. The issue of educating children in Islam is a very important issue. The process of Islamic education does not only begin when the child is born, but since in the womb, Islamic education has begun, even since the marriage was prepared. Thus, Islam which originates from the Qur'an and Hadith strongly upholds the values of Education. Baesd on the importance of the position of children in the family, then Islam also called for educating and managing the child's potential seriously. This call is to prevent children from being abandoned so that they grow into weak human beings in all matters both intellectually and socio-emotionally, but Islam pays attention to the formation of children's character to be better. In Islam there is the term of human being, this is the ultimate goal of Islamic education
\end{abstract}

Keywords: Children, education, Islam

\section{Pendahuluan}

Anak merupakan amanah Allah SWT dan sebagai generasi penerus bangsa memiliki berbagai potensi yang perlu dikembangkan secara optimal. Kemampuan anak yang luar biasa hendaknya dapat dikembangkan sesuai dengan tahapan perkembangannya. Untuk itu, perlu adanya pendidikan anak sejak dini untuk membantu pertumbuhan dan perkembangan anak secara optimal.

Persoalan anak bukan hanya kepentingan keluarga dari yang bersangkutan, tetapi juga kepentingan negara bahkan kepentingan internasional. Semua negara mengakui bahwa anak adalah masa depan bangsa dan negara. Pendidikan anak sudah seharusnya menjadi perhatian, agar kiranya setiap anak dapat menikmati hak-hak kemanusiannya sebagai warga negara antara lain mendapatkan pendidikan yang layak. Pendidikan anak selalu menarik dan menjadi topik pembicaraan para ahli pendidikan dari masa ke masa, seiring dengan perubahan zaman, para ahli pendidikan Islam juga dengan para pakar pendidikan barat, masing-masing memiliki pemikiran khas yang berbeda, namun masih ada benang merahnya, yakni perhatian mereka terhadap anak.

Kebutuhan anak akan arahan dan bimbingan hanya dapat dipenuhi melalui sebuah proses yang disebut pendidikan. Pendidikan bagi anak sangat penting, sebab tanpa pendidikan, anak tidak akan mampu mencapai perkembangan dan pertumbuhan fisik dan mental yang optimal.

Dalam pendidikan, anak pada hakikatnya adalah individu yang harus diperhatikan segala kebutuhannya oleh pendidik. Menurut Prescott, sebagaimana dikemukakan oleh Hamalik, kebutuhan peserta didik itu ada tiga, pertama kebutuhan 
fisiologis, yaitu berupa bahan-bahan dan keadaan yang esensial, kegiatan dan istirahat. Kedua kebutuhan sosial, yakni kebutuhan untuk menerima dan diterima orang lain; dan yang terakhir adalah kebutuhan ego atau integratif, yakni kontak dengan kenyataan dalam rangka mencari pengalaman, menambah kematangan diri sendiri, keseimbangan antara keberhasilan dan kegagalan, dan menemukan jati dirinya sendiri (Hamalik, 2007:96).

\section{Metode}

Kajian ini merupakan kajian literatur (library research). Sejumlah literatur tentang pendidikan anak dalam Islam dikaji dan ditelaah sesuai dengan perspektif hermenetika, sehingga hasil kajian ini masih terbuka untuk didialogkan dan didiskusikan.

\section{Hakikat Anak dalam Pendidikan Islam}

Secara umum dikatakan anak adalah seorang yang dilahirkan dari perkawinan antar seorang perempuan dengan seorang laki-laki, dengan tidak menyangkut bahwa seseorang yang dilahirkan oleh wanita meskipun tidak pernah melakukan pernikahan tetap dikatakan anak (Al Hamdani, 2017:237).

Menurut Kamus Besar Bahasa Indonesia anak adalah manusia yang masih kecil yang belum dewasa dan sedang dalam masa pertumbuhan dan perkembangan. Sebagai manusia kecil yang belum dewasa, ia membutuhkan bimbingan dan pendidikan dari orang tua dan pendidiknya dalam perkembangannya menuju kedewasaan. Muhammad Sa'id Mursi menjelaskan bahwa, anak-anak memiliki karakteristik sering meniru, suka menentang, banyak bergerak dan tidak mau diam, tidak dapat membedakan antara yang benar dan yang salah, banyak bertanya, memiliki ingatan yang tajam suka bermain dan bergembira juga berperasaan tajam (Mursi, 2001:16).

Adapun anak merupakan salah satu dari tiga periode perkembangan, yakni anak (childhood), remaja (adolescence), dan dewasa (adulthood). Periode anak dibagi menjadi beberapa periode yaitu: sebelum kelahiran (pranatal), masa bayi masa awal anak-anak, masa pertengahan dan akhir anak-anak (Sugandhi, 2011:9). Periode sebelum kelahiran merupakan masa kehidupan individu dimulai dari masa konsepsi hingga kelahiran, sekitar Sembilan bulan dalam kandungan. Periode ini merupakan masa pertumbuhan yang sangat luar biasa, dari satu sel tunggal yang beratnya kirakira 1/20 juta ons menjadi organisme yang sempurna dengan kemampuan otak dan tingkah lakunya.

Periode awal anak adalah periode perkembangan yang merentang dari akhir masa bayi hingga usia lima atau enam tahun. Selama masa ini, anak belajar untuk menjadi lebih mandiri dan memperhatikan dirinya. Mereka mengembangkan kesiapan sekolah dan menghabiskan banyak waktunya untuk bermain dengan teman sebayanya (Sugandhi, 2011:12).

Periode pertengahan dan akhir anak adalah masa perkembangan yang terjadi antara usia sekitar 6 hingga 10 atau 11 tahun. Anak usia ini sudah menguasai 
keterampilan dasar membaca, menulis, dan berhitung. Yang menjadi tema sentral pada periode ini adalah prestasi dan perkembangan pengendalian diri (Sugandhi, 2011:12).

Pengertian pendidikan Islam secara etimologi merupakan kata majemuk tak senyawa berasal dari kata pendidikan dan Islam. Pemakaian kata pendidikan Islam mempunyai konotasi dan bahasa sendiri daripada kata pendidikan umum. Tetapi makna semuanya beririsan dan sepakat dengan kata pendidikan (Saleh, 2001:3).

Dalam bahasa Indonesia pendidikan berasal dari kata "didik" dengan memberinya awalan"pe" dan akhiran "an" mengandung arti "perbuatan. Dalam bahasa Arab pendidikan dikenal oleh beberapa kata kunci di antaranya tarbiyah, ta'lim, tabyin, tazkiyah, tadris, dan ta'dib. Semua kata kunci itu hampir sudah tidak asing lagi bagi pegiat pendidikan Islam, bahkan sudah tertransliterasi ke dalam bahasa Indonesia.

Pengertian pendidikan Islam menurut beberapa pakar pendidikan Islam di antaranya Muhammad Quthb memberi pengertian pendidikan Islam sebagai usaha untuk melakukan pendekatan yang menyeluruh terhadap wujud manusia, baik dari segi jasmani maupun ruhani, baik dari kehidupan fisik maupun mentalnya, dalam melaksanakan kegiatannya di bumi ini (Qutb, 1984:27). Ali Ashraf menulis pengertian pendidikan Islam adalah pendidikan yang melatih sensibilitas (kepekaan) murid-murid sedemikian rupa sehingga perilaku kehidupan, langkah-langkah dan keputusan, serta pendekatan pada semua ilmu pengetahuan mereka diatur oleh nilainilai etika Islam yang dirasakan (Saleh, 2001:4).

Ahamad Marimba dalam bukunya pengantar filsafat Pendidikan Islam menyebutkan bahwa pendidikan Islam adalah bimbingan jasmani dan rohani berdasarkan hukum-hukum agama Islam menuju kepada terbentuknya kepribadian utama menurut ukuran-ukuran Islam. Muhammad Djaswidi Al Hamdani dalam bukunya Konsep Dasar Pendidikan Bernuansa Islami menyimpulkan bahwa pendidikan Islam adalah usaha untuk memanusiakan manusia. (Al Hamdani, 2017:50).

Secara ringkas Zakiah Daradjat menyebut bahwa pendidikan Islam merupakan pembentukan kepribadian muslim. Lebih menyeluruh dia mengatakan bahwa pendidikan Islam sebagaimana aktifitas Nabi saw yaitu usaha dan kegiatan menyampaikan seruan agama (dakwah), memberi teladan, melatih keterampilan berbuat, memberikan motivasi, dan menciptakan lingkungan sosial yang kesemuanya diarahkan dalam rangka pembentukan kepribadian Islam (Daradjat, 2011: 86).

Anak adalah titipan Allah yang harus dijaga oleh orang tua, bukan hanya harus dijaga tetapi anak juga harus diberikan kasih sayang dan pendidikan yang layak agar kelak anak tersebut menjadi orang yang berguna bagi agama, nusa dan bangsa. Pendidikan anak dalam Islam pada dasarnya merupakan bagian dari pendidikan Islam. Pendidikan Islam itu sendiri mempunyai tujuan yang diharapkan yaitu membuat seseorang berkepribadian menjadi insan kamil.

Pendidikan anak dalam Islam ini diharapkan menghasilkan manusia yang berguna bagi dirinya dan masyarakatnya serta senang mengamalkan dan mengembangkan ajaran Islam dalam berhubungan dengan Allah sebagai sang khaliq 
dan dengan manusia sebagai sesamanya. Anak seperti itu dalam kategori sehat dalam arti luas, yakni sehat fisik, mental emosional, mental intelektual, mental sosial, dan mental spiritual. Pendidikan hendaknya dilakukan sejak dini yang dapat dilakukan di dalam keluarga, sekolah maupun masyarakat. Dalam pendidikan harusnya mempunyai tiga aspek, yaitu aspek kognitif, afektif dan psikomotorik (Mansur, 2009:83).

Secara etimologis istilah tujuan sering diistilahkan dengan aim, goal, objective dan purporedan dalam bahasa arab disebut dengan ghayah, hadaf jamaknya ahdaf, dan maqasid. Tujuan adalah sesuatu yang diharapkan tercapai setelah sesuatu usaha atau kegiatan selesai. Oleh karena itu tujuan pendidikan anak dalam islam adalah suatu titik yang ingin dicapai oleh pendidikan anak dalam Islam setelah melakukan rangkaian proses kegiatan yang dilakukan oleh pendidik.

Dalam Kamus Besar bahasa Indonesia (KBBI), secara etimologi tujuan diartikan sebagai arah, maksud, tuntutan atau haluan. Sedangkan definisi secara terminologi dapat diartikan sebagai kondisi atau hasil akhir yang ingin dicapai oleh seseorang atau kelompok orang. Tujuan adalah sasaran yang hendak dicapai dan sekaligus sebagai pedoman dalam memberikan arah bagi segala aktifitas yang dilakukan (Mahmud, 2013:154).

Pendidikan Islam memiliki tujuan yang sangat universal dan mendalam. Adapun tujuan pendidikan Islam menurut Sayyid Sulthon di antaranya:

a. Tujuan intelektual atau keilmuan

Pendidikan Islam di antaranya bertujuan untuk mengembangkan kemampuan intelektual dan memiliki daya nalar dan sikap kritis yang tinggi, maka obyek ini meliputi alam raya dan manusia.

b. Tujuan moral

Pendidikan dalam bidang etika yaitu bertujuan untuk menciptakan manusia yang memiliki akhlak yang luhur, akhirnya terciptalah masyarakat yang menjunjung nilai- nilai luhur kemanusiaan seperti yang diajarkan oleh Islam, sehingga tercermin dalam prilaku yang adil, memahami persamaan sosial dan hak individu.

c. Tujuan agamis

Secara agamis, maka pendidikan Islam memuat misi penegakan agama untuk mempersiapkan kader-kader muslim yang taat dan patuh pada agama, mempersiapkan dan mempertahankan dan sekaligus menyiarkan agama (Huda, 2009:20-22).

Para ahli pendidikan yang lainpun telah memberikan definisi tentang tujuan pendidikan Islam, dimana rumusan atau definisi yang satu dengan yang lain berbeda, meskipun demikian, pada hakikatnya rumusan dari tujuan pendidikan Islam itu sama, mungkin hanya redaksi dan penekanannya saja yang berbeda. Berikut ini akan dikemukakan beberapa definisi tujuan pendidikan Islam yang dikemukakan oleh para ahli: (1) Naquib al-Attas menyatakan bahwa tujuan pendidikan yang penting harus diambil dari pandangan. Jika pandangan hidup itu Islam maka tujuannya adalah membentuk manusia sempurna (insan kamil) menurut Islam. (2) Abd ar-Rahman Saleh Abdullah mengungkapkan bahwa tujuan pokok pendidikan Islam mencakup 
tujuan jasmaniah, tujuan rohaniah dan tujuan mental. Shaleh Abdullah telah mengklarifikasikan tujuan pendidikan kedalam tiga bidang, yaitu fisik-material, ruhani-spiritual, dan mental emosional. Ketiganya harus diarahkan pada bentuk kesempurnaan. Ketiganya harus tetap dalam kesatuan yang tak terpisahkan. (3) Muhammad Athiyah al-Abrasyi merumuskan tujuan pendidikan Islam secara rinci. Dia menyatakan bahwa tujuan pendidikan Islam adalah untuk membentuk akhlak yang mulia, persiapan menghadapi kehidupan dunia-akhirat, persiapan untuk mencari rizki, menumbuhkan semangat ilmiah, dan mempersiapkan profesionalisme subyek didik. Dari semuanya harus menuju pada titik kesempurnaan yang salah satu indikatornya adalah adanya nilai tambah secara kuantitatif dan kualitatif (Roqib, 2009:27).

Bagi Asma Hasan Fahmi (mursyi, 1977:17), tujuan akhir pendidikan Islam dapat dirinci sebagai berikut: pertama tujuan keagamaan, kedua tujuan pengembangan akal dan akhlak, ketiga tujuan pengajaran kebudayaan dan yang keempat tujuan pendidikan kepribadian.

Salah satu komponen yang paling penting dalam pendidikan adalah materi pendidikan. Sebab apa artinya ada guru (orang tua) dan murid (anak-anak) kalau tidak ada materi pendidikan yang disampaikan. Oleh karena itu orang tua dan guru sebagai pendidik harus dapat mungkin meramu materi pendidikan yang akan disampaikan kepada anak-anaknya agar memiliki daya guna yang tinggi (Mahmud, 2013:155).

Materi pendidikan berarti muatan atau kandungan pelajaran yang disajikan kepada peserta didik. Adapun materi- materi yang menjadi tanggung jawab pendidik dalam pendidikan anak adalah sebagai berikut:

a. Pendidikan Iman

Yang dimaksud dengan pendidikan Iman adalah mengikat anak dengan dasardasar Iman, rukun Islam dan dasar-dasar syari'ah, sejak anak mulai mengerti dan dapat memahami sesuatu.

Adapun beberapa petunjuk mengenai pendidikan iman sebagaimana yang telah diwasiatkan oleh Rasulullah SAW meliputi:

1) Membuka kehidupan anak dengan kalimat Laa Ilaa ha illalllaah (Tiada Tuhan kecuali Allah). Hal ini terkait pula dengan anjuran mengumandangkan adzan di telinga kanan, dan iqamat di telinga kiri saat kelahiran anak. Upaya ini dimaksudkan agar kalimat Tauhid dan syi'ar masuk Islam itu merupakan suatu yang pertama masuk ke dalam pendengaran anak (Ulwan, 1995:152).

2) Mengenalkan hukum halal dan haram pada anak.

Hikmahnya adalah agar anak tumbuh besar dengan mengenal hukum-hukum Allah, terikat dengan hukum syariat dan selanjutnya ia hanya akan mengenal hukum dan undang-undang islam.

3) Membiasakan anak untuk beribadah sejak dini

Seorang pendidik hendaknya membiasakan memerintah anak untuk beribadah. Hal ini agar anak dapat mempelajari hukum-hukum ibadah ini sejak dalam 
masa pertumbuhan. Sehingga ketika anak tumbuh besar, ia telah terbiasa melakukan dan terdidik untuk mencintai Allah, melaksanakan hak-Nya, berpegang teguh kepadaNya (Ulwan, 1995:152).

Dari pemaparan tersebut, dapat disimpulkan bahwasanya pendidikan iman merupakan pendidikan yang paling penting dan paling utama dalam kehidupan dan peserta didik, karena pendidikan iman adalah pendidikan yang berkaitan dengan sang Pencipta, yaitu Allah SWT. Diharapkan dengan adanya pendidikan iman ini, peserta didik mampu menjalankan syari"at- syari"at yang diperintah oleh Allah dan menjadi orang- orang yang bertaqwa.

b. Pendidikan Moral

Yang dimaksud pendidikan akhlak adalah sejumlah prinsip-prinsip akhlak dan nilai-nilai moral yang harus ditanamkan kepada anak-anak, agar bisa dijadikan kebiasaan oleh anak sejak usia dini, lalu tertanam meningkat ke usia balig hingga perlahan-lahan tumbuh dan berkembang pada usia dewasa. Tentunya prinsip-prinsip akhlak dan nilai-nilai moral itu merupakan buah dari iman yang tertanam kokoh, dan pertumbuhan agama yang benar (Ulwan, 2015:91).

Materi pendidikan ini merupakan latihan membangkitkan nafsu-nafsu rubbuhiyah (ketuhanan) dan meredam nafsu-nafsu syaithaniyah. Pada materi ini peserta didik dikenalkan atau dilatih mengenai:

1) Perilaku atau akhlak yang mulia, sepertihalnya jujur, sabar, rendah hati dll

2) Perilaku akhlak tercela, seperti dusta, takabur, khianat dll

Setelah materi-materi tersebut disampaikan kepada peserta didik, maka diharapkan mereka memiliki perilaku- perilaku akhlak yang mulia dan menjauhkan prilaku- perilaku akhlak yang tercela (Muchtar, 2008:16).

c. Pendidikan Fisik (jasmani)

Di antara pendidikan yang dipikul Islam di atas pundak para pendidik, seperti ayah, ibu dan pengajar adalah pendidikan fisik. Hal ini dimaksudkan agar anak- anak tumbuh dewasa dengan kondisi fisik yang kuat, sehat, bergairah dan bersemangat.

Di antara pendidikan fisik yang digariskan dalam Islam adalah sebagai berikut:

1) Memberi nafkah kepada keluarga dan anak

2) Mengikuti aturan-aturan yang sehat dalam makanan, minuman dan tempat tinggal

3) Melindungi dari penyakit menular

4) Pengobatan terhadap penyakit

5) Membiasakan anak untuk berolahraga dan bermain ketangkasan

6) Menjauhkan anak diri dari perbuatan-perbuatan yang dilarang yang merusak fisik seperti merokok, onani, minuman keras dan narkoba, serta zina dan homoseksual (Ulwan, 2015:281). 
Berdasar pada penjelasan di atas, maka dapat disimpulkan bahwasanya pendidikan fisik ini lebih menuju pada pengajaran kepada anak didik untuk menjaga kondisi fisiknya dari hal-hal yang berbahaya bagi kesehatan anak.

d. Pendidikan Rasio (akal)

Pendidikan rasio atau pendidikan intelektual adalah membentuk dan membina pikiran anak dengan hal-hal yang bermanfaat, berupa ilmu-ilmu syar'i, ilmu pengetahuan dan budaya modern, pemikiran yang mencerahkan, dan kebudayaan. Dan diharapkan anak akan matang pikirannya serta menjadi orang yang berilmu dan berbudaya. Adapun pendidikan rasio atau intelektual ini dititikberatkan pada tiga hal utama, yaitu kewajiban mendidik, pencerahan pikiran dan memelihara kesehatan akal (Ulwan, 2015:141).

Dari kutipan di atas menjelaskan bahwa pendidikan rasio ialah membentuk pola pikir anak dengan segala sesuatu yang bermanfaat. Seperti ilmu-ilmu agama, kebudayaan dan peradaban. Dengan demikian, pikiran anak menjadi matang, bermuatan ilmu, kebudayaan dan sebagainya.

Dalam hal masalah pendidikan akal, maka tahap- tahap yang harus dijalankan oleh seorang pendidik terhadap anak didiknya yaitu kewajiban mengajar, menumbuhkan kesadaran berfikir, dan memelihara kesehatan rasio (Ulwan, 2015:281).

Berdasarkan uraian di atas, dapat disimpulkan bahwasanya pendidikan rasio itu lebih tertuju pada akal dan otak manusia agar semakin berkembang tentang ilmuilmu pengetahuan.

e. Pendidikan Psikologi (kejiwaan)

Pendidikan psikologis atau kejiwaan disini adalah mendidik anak supaya bersikap berani terbuka, mandiri, suka menolong, bisa mengendalikan amarah dan senang kepada seluruh bentuk keutamaan jiwa dan moral secara mutlak.

Tujuan dari pendidikan ini adalah membentuk, membina dan menyeimbangkan kepribadian anak. Sehingga ketika sudah dewasa, ia dapat melaksanakan kewajiban-kewajiban yang dibebankan pada dirinya secara sempurna. islam.

Beberapa faktor secara global, kemudian cara mengatasinya menurut kaidah

1) Sikap dan watak minder

Perasaan minder merupakan salah satu tabiat jelek bagi anak-anak. Gejala semacam ini biasanya dimulai pada usia 4 bulan. Setelah berusia satu tahun, perasaan minder akan lebih tampak pada anak. Yaitu ketika ia memalingkan wajahnya, menutup kedua mata atau wajahnya dengan kedua telapak tangannya kepada orang yang belum dikenalnya.

Pada usia 3 tahun, anak akan merasa minder ketika pergi ke sebuah rumah yang belum dikenal. Terkadang ia duduk dengan tenang dipangkuan ibu atau disampingnya sepanjang waktu, tanpa berbicara sepatah katapun. 
Adapun cara menanggulangi masalah ini, dapat dilakukan dengan membiasakan anak-anak bergaul dengan teman-temannya yang baik, dengan cara mengundang teman-teman sebaya kerumah secara intensif, atau dengan cara membawa mereka berkunjung ke rumah teman-teman sebayanya dan juga ke rumah kerabatnya.

Dengan cara pembiasaan ini, maka perasaan minder akan berkurang di dalam jiwa anak. Mereka akan memiliki sifat percaya diri dan akan selalu terdorong untuk berbicara benar, tanpa merasa takut kepada cercaan orang lain (Ulwan, 2015:335).

2) Penakut

Sikap penakut merupakan situasi kejiwaan yang berjangkit pada anak-anak kecil dan orang dewasa, laki-laki dan perempuan. Sikap ini kadang dianjurkan selama masih dalam batas alami anak-anak. Sebab merupakan media untuk menjaga dan menjauhkan anak dari berbagai marah bahaya. Tetapi jika itu melampaui batas-batas kewajaran dan alami, maka dapat menyebabkan kegoncangan jiwa pada diri anakanak. Hal ini dianggap sebagai suatu masalah kejiwaan yang harus di atasi dan diperhatikan.

\section{3) Rendah diri}

Perasaan rendah diri merupakan suatu kondisi kejiwaan yang berjangkit pada sebagian anak karena faktor-faktor pembawa sejak lahir, tekanan mental pendidikan atau ekonomi. Sikap ini termasuk salah satu fenomena kejiwaan yang paling berbahaya, karena bisa membawa anak kepada kehidupan yang hina, sengsara dan penuh dosa (Ulwan, 2015:352)

\section{f. Pendidikan Sosial}

Seperti diketahui bahwa anak memiliki dua tugas hubungan yang harus dilakukan dalam hidupnya, yaitu hubungan dengan Allah (habluminallāh) berupa ibadah mahdlah, dan hubungan dengan sesama manusia (habluminannās) berupa ibadah ghairmahdlah atau kemasyarakatan.

Dalam materi pendidikan sosial atau kemasyarakatan ini anak dikenalkan mengenai hal-hal yang terdapat atau terjadi di masyarakat serta bagaimana caranya hidup di dalam

masyarakat, misalnya pendidikan da'wah amar ma'ruf nahyi munkar, bersabar, juga pendidikan etika dalam masyarakat, mencakup etika pergaulan, berbicara dan juga berjalan (Huda, 2008:298). Dengan adanya materi pendidikan ini diharapkan anak atau peserta didik memiliki wawasan kemasyarakatan dan mereka dapat hidup serta berperan aktif di masyarakatnya secara benar (Muchtar, 2008:16).

Metode pendidikan anak dalam Islam, yaitu:

\section{1) Keteladanan}

Keteladanan merupakan sarana pendidikan yang paling penting. Hal ini dapat dipahami karena secara naluriah, dalam diri anak ada potensi untuk meniru hal-hal yang ada di sekitarnya. Pada usia dini, keteladanan orang tua sangat berpengaruh terhadap kepribadian anak. Segala yg dilakukan orang tua dianggapnya selalu benar 
dan paling baik. Maka secara otomatis, anak akan mudah menirunya (Baharits, 1996:54-55).

Proses peniruan biasanya terjadi pada anak usia dua tahun. Proses ini mengalami perkembangan yang luar biasa ketika anak berusia lima atau enam tahun. Akan tetapi, proses itu akan berjalan seimbang ketika anak sampai pada akhir masa kanak-kanak. Peniruan ini bersumber dari kecintaan anak yang murni kepada orang tuanya.

Anak belajar melalui keteladanan dan peniruan jauh lebih banyak dari pada yang diperkirakan oleh orang tuanya. Anak terpengaruh oleh perilaku orang tuanya; mulai dari komunikasi dengan tetangga, teman sejawat, yang biasanya tidak disadari oleh orang tuanya. Di samping itu, kecenderungan-kecenderungan psikologis orang tua juga menjadi kecenderungan anak, oleh karena itulah, keteladanan yang baik sejak dini merupakan metode yang tepat dalam pendidikan anak.

2) Ganjaran dan Hukuman (reward and Punishment)

Pemberian ganjaran kepada anak adalah hal penting bagi anak. Ganjaran tersebut harus diberikan dengan tetap memelihara keseimbangan antara ganajaran yang berupa materi dan ganjaran nonmateri, karena merupakan kesalahan jika hanya memberikan ganjaran berupa materi kepada anak. Akan tetapi, anak harus juga diberi ganjaran nonmateri, seperti pujian yang diberikan dihadapan orang lain (Mursi, 1998:103).

Ada beberapa media pemberian ganjaran pada anak, antara lain: a) berbicara pada anak menurut kadar kemampuan akalnya; b) memanggilnya dengan nama yang disukainya; c) hadiah materi; d) kalimat atau kata-kata yang baik; e) memberi maaf kepada anak atas kesalahan yang telah dilakukannya disertai penjelasan bahwa maaf itu diberikan karena ia telah melakukan suatu kebaikan; dan f) memberikan pujian kepada anak di hadapan orang lain (Mursi, 1998:103-104).

Adapun hukuman merupakan metode pendidikan yang diberikan jika nasihat, arahan, petunjuk, dan keteladanan telah gagal memberikan pengaruh yang baik kepada anak. Hukuman harus d lakukan secara bertahap, mulai dari yang paling ringan sampai yang paling berat, dengan tetap memperhatikan nilai-nilai pendidikan dalam penerapannya (Mursi, 1998:112).

Hukuman kepada anak dapat dilakukan dengan beberapa cara, di antaranya: dengan pandangan yang tajam, membentak, memuji anak lain dihadapannya, menghalanginya untuk mengerjakan hal yang disenanginya, menjewer, dan memukul. Memukul adalah cara hukuman terakhir jika cara lain tidak mampu memperbaiki kesalahan anak (Mursi, 1998:112-113).

3) Metode Kisah

Metode kisah adalah salah satu metode pendidikan yang berpengaruh pada anak. Para ulama salaf menyatakan bahwa kisah adalah salah satu prajurit Allah swt; dimana Allah swt meneguhkan hati para walinya dengan kisah itu (Mursi, 1998:119). Hal ini sebagaimana firman Allah "Dan semua kisah dari rasul-rasul kami, ceritakan kepadamu, ialah kisah-kisah yang dengannya kami teguhkan hatimu; dan dalam surat 
ini telah datang kepadamu kebenaran serta pengajaran dan peringatan bagi orangorang yang beriman" (Q.S Hud: 120).

Kisah-kisah yang dapat dijadikan sebagai metode pendidikan anak sangat beragam. Pendidik dapat memberikan antara lain kisah para nabi, kisah-kisah yang tercantum dalam al-Qur'an, kisah hewan yang tercampur dalam al-Qur'an, kisahkisah kenabian, seperti kisah juraij. Kisah perjalanan hidup Nabi saw, kisah para sahabat Nabi saw (mursi, 1998:120).

4) Metode Nasihat

Nasihat merupakan salah satu pendidikan yang berpengaruh dalam membentuk anak agar ia dapat menjalankan perannya sebagai makhluk pribadi dan makhluk sosial. Metode ini menjadi sangat berpengaruh dalam pendidikan, karena metode ini memiliki pengaruh yang besar dalam mengungkapkan pikiran anak akan hakikat segala sesuatu (Ulwan, 1992:653).

\section{Kesimpulan}

Anak adalah seorang yang dilahirkan dari perkawinan antar seorang perempuan dengan seorang laki-laki, dengan tidak menyangkut bahwa seseorang yang dilahirkan oleh wanita meskipun tidak pernah melakukan pernikahan tetap dikatakan anak. Pendidikan anak merupakan hal yang sangat penting dilakukan agar perkembangan jasmani dan ruhaninya dapat berkembang dengan baik dan ia juga dapat menjalankan perannya dimasyarakat dengan baik pula. Pendidikan anak adalah usaha sengaja yang dilakukan oleh orang dewasa untuk memimpin perkembangan jasmani dan ruhani anak, mulai dari masa pranatal sampai masa akhir anak, agar ia dapat menjalankan kehidupan dan memenuhi tujuan hidupnya secara lebih efektif dan efisien.

Pendidikan Islam adalah usaha untuk membentuk karakter manusia yang kamil dalam diri generasi Islam, supaya fungsional manusia sebagai khalifah Allah di bumi berjalan sebagaimana mestinya, yang berlandaskan Al Qur'an dan Hadis. Pendidikan anak dalam Islam, adalah suatu proses pembinaan, pengajaran, pengarahan dan bimbingan secara sadar oleh si pendidik terhadap perkembangan jasmani dan rohani peserta didik atau anak tentang suatu ilmu pengetahuan yang nantinya akan dapat membentuk akhlak mulia, menjadikan manusia yang beradab dan bertaqwa kepada Allah yang bersumber pada ajaran agama ke dalam diri peserta didik. Dari pemaparan di atas, dapat disimpulkan bahwasannya hakikat anak dalam perspektif pendidikan Islam dimaksudkan untuk peningkatan potensi spiritual anak dengan adanya ilmu pengetahuan dan membentuk anak agar menjadi manusia yang beriman dan bertakwa kepada Allah SWT dan berakhlak mulia. Akhlak mulia mencakup etika, budi pekerti, dan moral sebagai perwujudan dari tujuan pendidikan.

Beberapa metode pendidikan anak, yaitu keteladanan, ganjaran dan hukuman, kisah, dan nasihat. Materi-materi pendidikan anak dalam Islam sebagai berikut: pendidikan Iman, pendidikan moral, pendidikan fisik (jasmani), pendidikan rasio (akal), pendidikan psikologi (kejiwaan) dan pendidikan sosial. 


\section{DAFTAR PUSTAKA}

Ahmadi, Abu dan Soleh Munawar. (2005). Psikologi Perkembangan. Jakarta: Rineka Cipta.

Al Hamdani M. Djaswidi. (2017). Konsep Dasar Pendidikan Bernuansa Islami. Bandung: Media Cendekia.

Baharits, Adnan Hasan Shalih. (1996). Tanggung Jawab Ayah Terhadap Anak Laki-laki. Jakarta: Gema Insani Press.

Daradjat, Zakiah. (2011). Ilmu Pendidikan Islam. Jakarta : Bumi Aksara.

Hamalik, Oemar. (2007). Proses Belajar Mengajar. Jakarta: Bumi Aksara.

Huda, Miftahul. (2009). Idealitas Pendidikan Anak. Malang: UIN Malang Press.

Mahmud dkk. (2013). Pendidikan Islam dalam Keluarga. Jakarta: Akademi Permata press.

Mansur. (2009). Pendidikan Anak Usia Dini dalam Islam. Yogyakarta: Pustaka Pelajar.

Muchtar, Heri Jauhari. (2008). Fikih Pendidikan. Bandung: PT Remaja Rosdakarya Offset.

Mursi, Muhammad Sa'id. (1998). Fannu Tarbiyah al-Aulad fil al-Islam. Kairo: Dar athThaba'ah wa an-Nasyr al-Islamiyah.

Roqib, Moh. (2009). Ilmu Pendidikan Islam. Yogyakarta: PT LKiS

Saleh, Abdul Rachman. (2001). Pendidikan agama dan Keagamaan: Visi, Misi, dan Aksi. Jakarta: PT Gemawindu Pancaperkasa.

Sugandhi, Nani M. (2011). Perkembangan Peserta Didik. Jakarta: Raja Grafindo Persada. 
